\title{
Changing Patterns of Compliance with Protective Behavioral Recommendations in the Post First-Round COVID-19 Vaccine Period Among Healthcare Workers in Southern Ethiopia
}

\author{
Bewunetu Zewude ${ }^{\prime}{ }^{\prime}$ \\ Belayneh Melese ${ }^{2}$ \\ Enatihun Addis' \\ Weynishet Solomon' \\ 'Department of Sociology, College of \\ Social Sciences and Humanities, Wolaita \\ Sodo University, Wolaita Sodo, Ethiopia; \\ ${ }^{2}$ Department of Civics and Ethical \\ Studies, College of Social Sciences and \\ Humanities, Wolaita Sodo University, \\ Wolaita Sodo, Ethiopia
}

Background: Healthcare providers are facing an increasing threat as a result of confronting COVID-19. The aim of the present study was to assess the changes in compliance with the protective behavioral recommendations after taking the first round of COVID-19 vaccine among healthcare workers in Southern Ethiopia.

Methods: A cross-sectional study design was used in which quantitative data were collected using a survey method. A self-administered questionnaire was distributed to a sample of healthcare workers who were selected through a multi-stage cluster sampling technique. From the 403 healthcare workers who participated in the survey, 236 properly completed and returned the questionnaires. After inserting it into SPSS software, data were analyzed using frequency tables, percentage distributions, and logistic regression coefficients.

Results: While $30.5 \%$ of the healthcare workers disclosed a decreasing experience of wearing mask, 30.1\% revealed that their experience of regularly washing hands has decreased after taking the first round of COVID-19 vaccine. The main reasons for not regularly wearing a mask are its inconvenience $(60 \%)$, the need to appear indifferent (38.5\%), and that they cannot afford to buy one due to its cost (15.4\%). Above all, respondents' level of compliance with regular wearing of a mask is significantly associated with sex (OR $=3.165, \mathrm{P}<0.05$; 95\% CI: 1.186-8.448), the type of organization in which they are currently working $(\mathrm{OR}=3.553, \mathrm{P}<0.05 ; 95 \% \mathrm{CI}$ : 1.185-10.647), knowing someone ever infected by COVID-19 (OR $=0.091, \mathrm{P}<0.001 ; 95 \% \mathrm{CI}: 0.030-0.275)$, and the belief that COVID-19 causes a severe illness (OR $=0.249, \mathrm{P}<0.05$; 95\% CI: 0.299-2.615).

Conclusion: We have found significant reductions in adherence to the usual protective mechanisms. Therefore, increased access to the personal protective materials, including water, should be created and the healthcare workers should be continuously informed about the serious consequences of ignorance of self-protective behavior.

Keywords: compliance, change, COVID-19, healthcare workers, first-round vaccine

\section{Introduction}

Healthcare providers usually face the major professional responsibility of responding to any outbreak such as COVID-19 that puts them at a higher risk of infection. ${ }^{1-3}$ According to the findings of a study conducted by Liu et al., ${ }^{4}$ healthcare providers are challenged by working in an unfamiliar context that leads them to exhaustion resulting from heavy workloads and protective gear, and the fear of becoming
Correspondence: Bewunetu Zewude Email bewunetuzewude@gmail.com 
infected. Therefore, healthcare workers should take all the necessary precautionary measures, including an appropriate and regular use of personal protective equipment, providing adequate space to allow social distance between patients and healthcare workers, rigorous cleaning and disinfection to eliminate contamination, and ensuring the presence of adequate rooms for the purpose of isolating patients with suspected or confirmed cases of COVID-19. ${ }^{3,5}$

It is indicated that healthcare workers are facing an increasing threat as a result of confronting severe and contagious diseases, including COVID-19. ${ }^{6}$ Furthermore, the COVID-19 pandemic remains a major cause of death which has claimed the lives of many well trained and experienced healthcare professionals, especially in Europe. ${ }^{7}$ Many healthcare workers have died after contracting the virus while treating patients infected by COVID-19. ${ }^{8}$ The loss of such trained manpower has enormous economic and social consequences, the impact of which increases especially in developing countries such as Ethiopia where the cost of training medical personnel is relatively high. ${ }^{9-12}$ The Coronavirus pandemic has also resulted in healthcare workers facing shortages of personal protective materials against COVID-19. ${ }^{13}$ Woyessa et al. ${ }^{6}$ found that healthcare workers in Western Ethiopia are generally unwilling to continue working under circumstances where the spread of COVID-19 pandemic reached at its peak. According to the Health and Safety Authority, ${ }^{10}$ safety and health guidelines are applicable to all workers in all settings, but the extent to which they are effectively implemented relies on many factors, including the adequacy of its facilities.

The important determinants of risk of disease transmission to healthcare workers include working in close proximity to a patient, risks associated with whether the patient wore a mask in the hospital, the absence of evidence-based and practical infection control policies, and the lack of communication about safety within healthcare organizations. ${ }^{14}$ Moore et al. ${ }^{15}$ noted that organizational circumstances, such as a positive safety climate are associated with increased healthcare workers' adherence to universal precautions against SARS and other respiratory pathogens and suggested that providing rigorous training to healthcare workers can serve as an effective tool in changing their behavior. Derksen et al. ${ }^{16}$ found frequent shortage of water, the presence of a culture promoting tolerance of dirtiness by the community, and healthcare organizational culture to be the main factors affecting the safety of healthcare workers. Moreover, Diwan et al. ${ }^{17}$ added scarcity of resources and the perception that priority is not given to hand hygiene at various levels serving as barriers to maintaining good hand hygiene among healthcare workers in rural India. Boti et al. ${ }^{18}$ identified various institutional, cultural, social, and personal barriers, including negligence, inadequate training for healthcare workers, and poor supportive supervision, hindering the effective implementation of public health measures for containing the fast spread of COVID-19 in Southern Ethiopia. DeJoy et al. ${ }^{19}$ argues that the effort of minimizing the risks of exposure to pathogens among healthcare workers requires a system-level perspective. Marjadi et al. ${ }^{20}$ stressed the need for interventions that focus on long-term community education to successfully protect healthcare workers from infection and fatalities.

Hailu et al. ${ }^{7}$ found low compliance to occupational health safety measures among healthcare workers in North Showa of Ethiopia. According to Majeed et al. ${ }^{21}$ surgeons working in private healthcare facilities are relatively at a higher risk of infection by COVID-19 when treating COVID-19 patients and the lack of relevant policies is affecting their medical practices. A study conducted in Saudi Arabia by Alwazzan et al. ${ }^{22}$ revealed that dental professionals have a good knowledge about COVID-19 and preventive mechanisms. Gralton et al. ${ }^{23}$ found that intention to use a facemask was poor for care in single rooms but improved when patient contact is expected and when entering into multi-bed rooms in which perceived protectiveness of pre-exposure prophylaxis, vaccination, and a minimum 1 meter risk zone predicted facemask use among healthcare workers.

Derksen et $\mathrm{al}^{16}$ found an increasing compliance and adaptation to hand hygiene behavior among obstetric healthcare workers in Germany to prevent COVID-19 infection where the intention to sanitize hands is significantly associated with health workers' level of selfefficacy. On the other hand, Marjadi et al. ${ }^{20}$ uncovered that compliance to hand hygiene practices among rural Indonesian healthcare workers is poor and when it is done, it is more likely to be undertaken after direct contact with patients. Furthermore, Diwan et al. ${ }^{17}$ found high but varying among groups self-reported practices of hand hygiene among healthcare workers in rural India where previous training on the topic determines the level of selfreported practice of hand hygiene. With these inconsistent findings pertaining to the issue at hand, healthcare workers' level of compliance with the universal behavioral recommendation to contain the spread of COVID-19 
after taking the first- round of COVID-19 vaccine is hardly known. The purpose of the present research was, therefore, to assess the changes (if any) to the practices of personal protective measures among healthcare workers after receiving the first round of COVID-19 vaccine. The study also aimed at comparing the pre and post firstround COVID-19 vaccine level of compliance to the behavioral recommendations among the target groups.

\section{Materials and Methods Research Design}

A cross sectional study was conducted in which quantitative data were collected using a survey method from a representative sample of healthcare workers providing healthcare services in various healthcare facilities of Southern Ethiopia.

Research Site and Selection of Participants

The present study was undertaken during the period in which the population "most at risk of infection to COVID19 " had taken the first round of COVID-19 vaccine and were waiting to take the remaining dose. Therefore, the target populations of the present research are all people in Southern Ethiopia that have taken the first round of COVID-19 vaccine. Unfortunately, it was only the healthcare workers and a few elderlies having chronic illnesses that had the chance to be vaccinated given the lesser amount of vaccines that the government could supply. With the poor clients' basic information archival experiences of healthcare facilities in the study area, tracing the addresses of the other groups who have taken the vaccine (elderlies with chronic illnesses) was hardly possible for the researchers. Consequently, the survey populations of the present study are all healthcare workers in Southern Ethiopia that have taken the first round of COVID-19 vaccine. A multi-stage cluster sampling technique was used to draw the sample of healthcare workers in Southern Ethiopia. In order to determine the sample size, the researchers applied Cochran's (1977) formula for calculating sample size of unknown population as:

$$
\mathrm{n}=\frac{\mathrm{z}^{2} \times \mathrm{p}(1-\mathrm{p})}{\mathrm{e}^{2}} ;=1.96^{2} \times 0.5(1-0.5) / 0.05^{2}=384
$$

Where, $\mathrm{n}$ is the sample size, $\mathrm{z}$ is the selected critical value of desired confidence level, $p$ is the estimated proportion of an attribute that is present in the population. Then, the final sample units were chosen on the basis of probability proportionate to size sampling technique. The major inclusion criteria to participate in the study were taking the first- round of COVID-19 vaccine and willingness to be included in the survey. Healthcare workers who have not taken the first- round of COVID-19 vaccine for various reasons and those that were not willing to participate in the study were excluded.

\section{Research Method}

A survey research method was used to generate primary data in which a self-administered questionnaire was designed and randomly distributed to a sample of healthcare workers serving in various private, public, charity and other types of healthcare facilities in Southern Ethiopia. Before the final questionnaire was duplicated and distributed, we have tested its validity on 30 healthcare workers in Wolaita Sodo town. After receiving feedback and making all the necessary corrections, we duplicated the questionnaire proportional to the calculated sample size after considering a $5 \%$ non-response rate. Finally, after obtaining consent, trained data collectors distributed the questionnaires to healthcare workers working in Wolaita Sodo, Hawassa, Boditi, Areka, and Yirgalem towns of Southern Ethiopia.

\section{Instrumentation}

The questionnaire that served as an instrument of data collection in our research was partly taken from the studies of Zewude et al. ${ }^{24}$ and was adapted to the purpose at hand while most other questions were developed by the researchers. The questionnaire has two main sections: questions related to the socio-demographic characteristics of respondents and questions aimed at assessing research participants' attitude and experiences of implementing the personal protective behavioral recommendations. The first section of the tool comprises variables such as sex, age, education, occupation, marital status, and the presence of children. In addition, this part also includes questions that aim at measuring respondents' perceptions of COVID-19 and their previous contact or experience with the disease. For instance, respondents were asked their perception regarding whether COVID-19 causes severe illnesses, if they know someone who was ever infected by or died of COVID-19, and whether they believe that they can be infected by COVID-19, their belief about the likelihood of dying from COVID-19, all with response categories of (1) Yes, and (2) No.

The next section of the questionnaire aimed at measuring respondents' experiences in practicing the common personal protective behavioral recommendations. The 
main purpose of the section was to compare healthcare workers' level of compliance with the recommended safety measures before and after taking the first round of COVID-19 vaccine and to measure the changes (if any) in the compliance between the before and after of taking the vaccine. It involves questions such as "Do you regularly wear a mask?", "Have you been regularly wearing a mask before taking the first round of COVID-19 vaccine?", "How do you evaluate your experience of wearing a mask after taking the first round COVID-19 compared to your situation prior to taking the vaccine?", "Do you frequently wash your hands after touching objects?", "Do you regularly wear a mask after taking the first round of COVID-19 vaccine?", all with response categories of "yes" and "no". Moreover, the section also includes questions that intend to assess the extent to which respondents believe in the effectiveness of the protective behavioral recommendations. For instance, we have asked respondents "Do you believe that a mask can prevent the transmission of COVID-19?", and "Do you believe that cleaning hands immediately after touching any object can prevent COVID-19?" with response categories of "yes" and "no". Furthermore, with expectation of noncompliance to the behavioral recommendations, potential reasons for such non-compliance were also included in the section.

\section{Method of Data Analysis}

The data were first checked for completeness. Questionnaires that were correctly filled were inserted into SPSS software. Then, data analysis was conducted using statistical techniques, including percentages, frequency distributions, and logistic regression analysis. Using descriptive statistics, we presented data regarding the frequency and percentage distribution of responses pertaining to respondents' socio-demographic characteristics, level of compliance to the protective behavioral recommendations, reasons for non-compliance, and beliefs about the protective behavioral recommendations. The logistic regression test was used to examine the association between the socio-demographic characteristics of respondents and their compliance to the protective behavioral recommendations. In an attempt to avoid multicollinearity, the variables for the regression analysis were selected after calculating correlation coefficients for all pairs of predictor variables.

\section{Results}

The mean age of respondents is 32.1 ( $\mathrm{SD}=7.45)$. According to the data presented in Table 1, the majority of the research participants are females $(51.7 \%)$ and males constitute $48.3 \%$. Moreover, $70.8 \%$ of respondents are married and most (63.1\%) of them reported to have children. In addition, the educational status of research participants reveals that $62.7 \%$ of them are BA/BSC Degree holders, followed by college diploma graduates (24.6\%). Furthermore, the occupational distribution of respondents shows that nurses $(40.3 \%)$, health officers $(17.8 \%)$, pharmacists $(11.9 \%)$ and administrative staff $(11.4 \%)$ respectively have the highest percentage in the distribution. It is also shown that $47.5 \%$ of the research participants work in publicly owned healthcare organizations followed by those working in charity organizations (38.1\%). According to the data, $74.6 \%$ of the respondents disclosed that they know someone ever infected by COVID-19, 47\% know someone who died from COVID-19, 52.1\% of them think that they are likely to be infected by COVID-19, 77.5\% think that COVID-19 causes a severe illness, and 39\% of the respondents believe that they are not likely to die if infected by COVID-19.

\section{Changing Patterns of Compliance with Protective Behavioral Recommendations}

Data presented in Table 2 show the attitude and changing patterns of healthcare workers' compliance with the protective behavioral recommendations before and after receiving the first round of COVID-19 vaccine. Accordingly, $95.8 \%$ of respondents believe that wearing a mask prevents the transmission of COVID-19 while $78.9 \%$ reported that they would regularly wear a mask. In addition, $30.5 \%$ of the healthcare workers disclosed a decreasing experience of wearing a mask after taking the first round of COVID-19 vaccine. Furthermore, 97.5\% of respondents believe that cleaning hands immediately after touching objects would help to prevent COVID-19. While $88.6 \%$ of healthcare workers reported to wash their hands after touching objects, $30.1 \%$ revealed that their experience of regularly washing hands has decreased after taking the first round of COVID-19 vaccine. Moreover, $91.5 \%$ of respondents clean their hands with disinfectants where there is no access to water and soap. It is also found that the experience of cleaning hands with disinfectants has decreased after taking the first round of COVID-19 vaccine for $30.5 \%$ of respondents. Above all, 
Table I Socio-Demographic Characteristics of Respondents

\begin{tabular}{|c|c|c|}
\hline Variables & Categories & $\begin{array}{l}\text { Frequency } \\
\text { (\%) }\end{array}$ \\
\hline Sex & $\begin{array}{l}\text { Male } \\
\text { Female }\end{array}$ & $\begin{array}{l}114(48.3 \%) \\
122(51.7 \%)\end{array}$ \\
\hline Marital status & $\begin{array}{l}\text { Never married } \\
\text { Married } \\
\text { Divorced } \\
\text { Widowed }\end{array}$ & $\begin{array}{l}61(25.8 \%) \\
167(70.8 \%) \\
5(2.1 \%) \\
3(1.3 \%)\end{array}$ \\
\hline Having children & $\begin{array}{l}\text { Yes } \\
\text { No }\end{array}$ & $\begin{array}{l}149(63.1 \%) \\
87(36.9 \%)\end{array}$ \\
\hline Educational status & $\begin{array}{l}\text { Never } \\
\text { attended } \\
\text { school } \\
\text { Primary school } \\
(I-8) \\
\text { Secondary } \\
\text { school (9-12) } \\
\text { College } \\
\text { diploma } \\
\text { BA/BSC } \\
\text { Degree } \\
\text { MA/MSc } \\
\text { Degree \& } \\
\text { above }\end{array}$ & $\begin{array}{l}2(0.8 \%) \\
10(4.2 \%) \\
2(0.8 \%) \\
58(24.6 \%) \\
148(62.7 \%) \\
16(6.8 \%)\end{array}$ \\
\hline Occupational status & $\begin{array}{l}\text { Medical doctor } \\
\text { Health officer } \\
\text { Administrative } \\
\text { staff } \\
\text { Nurse } \\
\text { Pharmacist } \\
\text { Medical } \\
\text { laboratory } \\
\text { technician } \\
\text { Security } \\
\text { Janitor }\end{array}$ & $\begin{array}{l}20(8.5 \%) \\
42(17.8 \%) \\
27(11.4 \%) \\
95(40.3 \%) \\
28(11.9 \%) \\
12(5.1 \%) \\
7(3 \%) \\
5(2.1 \%)\end{array}$ \\
\hline $\begin{array}{l}\text { Type of organization in which } \\
\text { respondents are currently working }\end{array}$ & $\begin{array}{l}\text { Public } \\
\text { Private } \\
\text { Charity }\end{array}$ & $\begin{array}{l}\text { I I } 2 \text { (47.5\%) } \\
34(14.4 \%) \\
90(38.1 \%)\end{array}$ \\
\hline $\begin{array}{l}\text { Do you know someone ever } \\
\text { infected by COVID-19? }\end{array}$ & $\begin{array}{l}\text { Yes } \\
\text { No }\end{array}$ & $\begin{array}{l}176(74.6 \%) \\
60(25.4 \%)\end{array}$ \\
\hline $\begin{array}{l}\text { Do you know someone who died } \\
\text { of COVID-I9? }\end{array}$ & $\begin{array}{l}\text { Yes } \\
\text { No }\end{array}$ & $\begin{array}{l}\text { III (47\%) } \\
125(53 \%)\end{array}$ \\
\hline $\begin{array}{l}\text { Do you think you can be infected } \\
\text { by COVID-19? }\end{array}$ & $\begin{array}{l}\text { Yes } \\
\text { No }\end{array}$ & $\begin{array}{l}123(52.1 \%) \\
113(47.9 \%)\end{array}$ \\
\hline $\begin{array}{l}\text { Do you think COVID-19 causes } \\
\text { a severe illness? }\end{array}$ & $\begin{array}{l}\text { Yes } \\
\text { No }\end{array}$ & $\begin{array}{l}183(77.5 \%) \\
53(22.5 \%)\end{array}$ \\
\hline
\end{tabular}

(Continued)
Table I (Continued).

\begin{tabular}{|l|l|l|}
\hline Variables & Categories & $\begin{array}{l}\text { Frequency } \\
\text { (\%) }\end{array}$ \\
\hline $\begin{array}{l}\text { Do you think you are likely to die if } \\
\text { infected by COVID-19? }\end{array}$ & $\begin{array}{l}\text { Yes } \\
\text { No }\end{array}$ & $\begin{array}{l}92(39 \%) \\
144(61 \%)\end{array}$ \\
\hline Total & & $236(100 \%)$ \\
\hline
\end{tabular}

$31.4 \%$ of healthcare workers disclosed an overall decreasing trend of compliance with the protective behavioral recommendations whereas $45.3 \%$ reported that it remained unchanged even after taking the first round of COVID-19 vaccine.

The data presented in Table 3 show the changing patterns of compliance with the protective behavioral recommendations among the healthcare workers. According to the data, we have found a change, characterized by decreasing trends, in compliance with most elements of the protective behavioral recommendations after receiving the first round of COVID-19 vaccine. For instance, healthcare workers who have been always wearing mask before receiving the first round of the vaccine were 203 (86\%) which decreased to 155 (65.7\%) after taking the vaccine. Similarly, we have found a change in regular hand hygiene practices from its previous $76.3 \%$ level before taking the vaccine to $50 \%$ after taking the first round of COVID-19 vaccine. In addition, practices of covering one's mouth and nose with flexed elbow or tissue when coughing or sneezing has decreased from its relatively better level $(52.5 \%)$ before taking the vaccine to $49.6 \%$ after the vaccine. Furthermore, participation in mass events on a regular basis has increased from $24.6 \%$ before receiving the vaccine to $26.3 \%$ after taking the vaccine.

Table 4 contains data pertaining to the distribution of respondents in terms of reasons for not complying with the various personal protective behavioral recommendations. It is found that the main reason of respondents for not regularly wearing a mask is its inconvenience $(60 \%)$, followed by the need to appear indifferent because most people around the respondents do not wear a mask (38.5\%), and cannot afford buying one due to its cost (15.4\%). Moreover, lack of access to water/soap has been found to be the major reason $(40.5 \%)$ for the healthcare workers not to frequently wash hands after touching 
Table 2 Patterns of Compliance with Protective Behavioral Recommendations Before and After Taking the First- Round of COVID-19 Vaccine

\begin{tabular}{|c|c|c|}
\hline Variables & Categories & $\begin{array}{l}\text { Frequency } \\
\text { (\%) }\end{array}$ \\
\hline \multirow[t]{2}{*}{ Do you believe that a mask can prevent the transmission of COVID-19? } & Yes & $226(95.8 \%)$ \\
\hline & No & $10(4.2 \%)$ \\
\hline \multirow[t]{2}{*}{ Do you regularly wear a mask? } & Yes & $186(78.9 \%)$ \\
\hline & No & $50(21.2 \%)$ \\
\hline \multirow[t]{2}{*}{ Have you been regularly wearing a mask before taking the first- round of COVID-I9 vaccine? } & Yes & $206(87.3 \%)$ \\
\hline & No & $30(12.7 \%)$ \\
\hline \multirow{4}{*}{$\begin{array}{l}\text { How do you evaluate your experience of wearing a mask after taking the first round of COVID-19 } \\
\text { vaccine compared to your situation prior to taking the vaccine? }\end{array}$} & Increased & $44(18.6 \%)$ \\
\hline & Decreased & $72(30.5 \%)$ \\
\hline & Unchanged & $114(48.3 \%)$ \\
\hline & $\begin{array}{l}\text { Cannot recognize the } \\
\text { difference }\end{array}$ & $6(2.5 \%)$ \\
\hline \multirow[t]{2}{*}{ Do you believe that cleaning hands immediately after touching any object can prevent COVID-I9? } & Yes & $230(97.5 \%)$ \\
\hline & No & $6(2.5 \%)$ \\
\hline \multirow[t]{2}{*}{ Do you frequently wash your hand after touching objects? } & Yes & $209(88.6 \%)$ \\
\hline & No & $27(11.4 \%)$ \\
\hline \multirow[t]{2}{*}{ Have you been regularly washing your hands before taking the first round of COVID-19 vaccine? } & Yes & $215(91.1 \%)$ \\
\hline & No & $21(8.9 \%)$ \\
\hline \multirow{4}{*}{$\begin{array}{l}\text { How do you evaluate your experience of regularly washing your hands after taking the first round of } \\
\text { COVID-19 vaccine compared with your experience prior to taking the vaccine? }\end{array}$} & Increased & $49(20.8 \%)$ \\
\hline & Decreased & $71(30.1 \%)$ \\
\hline & Unchanged & $113(47.9 \%)$ \\
\hline & $\begin{array}{l}\text { Cannot recognize the } \\
\text { difference }\end{array}$ & $3(1.3 \%)$ \\
\hline \multirow{2}{*}{$\begin{array}{l}\text { Where you cannot get access to water and soap, do you clean your hands with disinfectants after taking } \\
\text { the first round of COVID-19 vaccine? }\end{array}$} & Yes & $216(91.5 \%)$ \\
\hline & No & 20 (8.5\%) \\
\hline \multirow{4}{*}{$\begin{array}{l}\text { How do you evaluate your experience of cleaning your hands with disinfectants after taking the first } \\
\text { round of COVID-19 vaccine compared with your experience prior to taking the vaccine? }\end{array}$} & Increased & 43 (I8.2\%) \\
\hline & Decreased & 72 (30.5\%) \\
\hline & Unchanged & II 2 (47.5\%) \\
\hline & $\begin{array}{l}\text { Cannot recognize the } \\
\text { difference }\end{array}$ & 9 (3.8\%) \\
\hline
\end{tabular}

(Continued) 
Table 2 (Continued).

\begin{tabular}{|c|c|c|}
\hline Variables & Categories & $\begin{array}{l}\text { Frequency } \\
\text { (\%) }\end{array}$ \\
\hline \multirow{4}{*}{$\begin{array}{l}\text { How do you generally evaluate your overall trends of complying with the protective behavioral } \\
\text { recommendations against COVID-19 after taking the first round of the vaccine? }\end{array}$} & Increased & 47 (I9.9\%) \\
\hline & Decreased & 74 (3।.4\%) \\
\hline & Unchanged & 107 (45.3\%) \\
\hline & $\begin{array}{l}\text { Cannot recognize the } \\
\text { difference }\end{array}$ & $8(3.4 \%)$ \\
\hline \multirow{2}{*}{$\begin{array}{l}\text { After taking the first round of COVID-19 vaccine, have you started to feel secure from being infected by } \\
\text { COVID-19? }\end{array}$} & Yes & I 88 (79.7\%) \\
\hline & No & 48 (20.3\%) \\
\hline \multirow{2}{*}{$\begin{array}{l}\text { Do you think the feeling of security you developed after receiving the first round of COVID-19 vaccine } \\
\text { has affected your previous caution against COVID-19? }\end{array}$} & Yes & 97 (4I.1\%) \\
\hline & No & 139 (58.9\%) \\
\hline
\end{tabular}

objects, followed by the use of chemical disinfectants as a preferred alternative $(27 \%)$, and the belief that the first round of COVID-19 vaccine is sufficient to prevent infection (16.2\%). Furthermore, lack of access to hand sanitizer/alcohol (27.6\%), practices of avoiding touching objects having the potential of transmitting COVID-19 (24.1\%), and the belief that the first round of COVID-19 vaccine is sufficient to prevent infection (20.7\%) have been found to be the main reasons for the healthcare workers not cleaning their hands with disinfectants after touching objects during the periods after receiving the first round of COVID-19 vaccine.

\section{Factors Associated with Compliance with Protective Behavioral Recommendations}

The results of binary logistic regression analysis presented in Table 5 show the factors associated with the practices of regular mask wear among healthcare workers. The findings reveal that respondents' compliance with regular wearing of a mask is significantly associated with the sex of respondents $(\mathrm{OR}=3.165, \mathrm{P}<0.05 ; 95 \% \mathrm{CI}$ : 1.186 $8.448)$, the type of organization in which they are currently working $(\mathrm{OR}=3.553, \mathrm{P}<0.05 ; 95 \% \mathrm{CI}: 1.185-10.647)$, knowing someone ever infected by COVID-19 (OR = $0.091, \mathrm{P}<0.001 ; 95 \% \mathrm{CI}: 0.030-0.275)$, and the belief that COVID-19 causes a severe illness (OR $=0.249$, $\mathrm{P}<0.05$; 95\% CI: 0.299-2.615). In other words, females, healthcare workers serving in public healthcare organizations, those that are exposed to someone ever infected by COVID-19, and healthcare workers who believe that they would die if infected by COVID-19 are more likely to regularly wear a mask.

\section{Discussion}

Under the circumstances of the developing countries such as Ethiopia where access to COVID-19 vaccine for every citizen is difficult to achieve, the most important way to control the disease among the population is regularly maintaining hand hygiene and regular wearing of face masks, among other things. ${ }^{26}$ In response to the outbreak and spread of COVID-19, countries across the world have been implementing all the recommended safety measures to contain the spread of the virus. ${ }^{5,27}$ The absence of an established set of drugs to manage the already infected patients $^{25}$ further increases the importance of using these safety measures. Nevertheless, regardless of the advocacies made by the media and numerous organizations about the need for preventing the spread of the pandemic including the various ways of transmission, there still exists a gap as far as compliance to regular implementation of the preventive mechanisms within communities is concerned. ${ }^{28}$ The purpose of the present research was to examine the changes in the patterns of compliance among healthcare workers after taking the first round of COVID19 vaccine.

The results of the study indicated that $78.9 \%$ of healthcare workers reported that they would regularly wear a mask. In addition, $30.5 \%$ of the healthcare workers disclosed a decreasing experience of wearing a mask after taking the first round of COVID-19 vaccine. While 
Table 3 Changing Patterns of Compliance with Protective Behavioral Recommendations Before and After Taking the First Round of COVID-19 Vaccine

\begin{tabular}{|c|c|c|c|}
\hline \multirow[t]{2}{*}{ Variables/Questions } & \multirow[t]{2}{*}{ Categories } & \multicolumn{2}{|c|}{ Frequency (\%) } \\
\hline & & Before & After \\
\hline Wearing a (medical) mask & $\begin{array}{l}\text { Always } \\
\text { Occasionally } \\
\text { Never }\end{array}$ & $\begin{array}{l}203(86 \%) \\
33(14 \%) \\
-\end{array}$ & $\begin{array}{l}\text { I } 55(65.7 \%) \\
80(33.9 \%) \\
\text { I (0.4\%) }\end{array}$ \\
\hline Frequent hand hygiene (use hand sanitizers, recurrent washing of hands with soaps, etc.) & $\begin{array}{l}\text { Always } \\
\text { Occasionally } \\
\text { Never }\end{array}$ & $\begin{array}{l}180(76.3 \%) \\
56(23.7 \%) \\
-\end{array}$ & $\begin{array}{l}\text { I I } 8 \text { (50\%) } \\
\text { I I (49.6\%) } \\
\text { I (0.4\%) }\end{array}$ \\
\hline Keeping adequate (up to 2 meters) physical distance & $\begin{array}{l}\text { Always } \\
\text { Occasionally } \\
\text { Never }\end{array}$ & $\begin{array}{l}57(24.2 \%) \\
137(58.1 \%) \\
42(17.8 \%)\end{array}$ & $\begin{array}{l}35(14.8 \%) \\
150(63.6 \%) \\
5 \mid(21.6 \%)\end{array}$ \\
\hline Keeping a mask clean (by washing or replacing it with a new one) & $\begin{array}{l}\text { Always } \\
\text { Occasionally } \\
\text { Never }\end{array}$ & $\begin{array}{l}2 \mathrm{II}(89.4 \%) \\
24(10.2 \%) \\
\mathrm{I}(0.4 \%)\end{array}$ & $\begin{array}{l}205(86.9 \%) \\
29(12.3 \%) \\
2(0.8 \%)\end{array}$ \\
\hline Covering mouth and nose with flexed elbow or tissue when coughing or sneezing & $\begin{array}{l}\text { Always } \\
\text { Occasionally } \\
\text { Never }\end{array}$ & $\begin{array}{l}\text { I } 24(52.5 \%) \\
\text { I06 (44.9\%) } \\
6(2.5 \%)\end{array}$ & $\begin{array}{l}\text { II (49.6\%) } \\
\text { III (47\%) } \\
8(3.4 \%)\end{array}$ \\
\hline Staying at home when feel sick/symptomatic & $\begin{array}{l}\text { Always } \\
\text { Occasionally } \\
\text { Never }\end{array}$ & $\begin{array}{l}84(35.6 \%) \\
102(43.2 \%) \\
50(21.2 \%)\end{array}$ & $\begin{array}{l}86(36.4 \%) \\
101(42.8 \%) \\
49(20.8 \%)\end{array}$ \\
\hline Shaking hands with any person & $\begin{array}{l}\text { Always } \\
\text { Occasionally } \\
\text { Never }\end{array}$ & $\begin{array}{l}25(10.6 \%) \\
119(50.4 \%) \\
92(39 \%)\end{array}$ & $\begin{array}{l}25(10.6 \%) \\
122(51.7 \%) \\
89(37.7 \%)\end{array}$ \\
\hline Touching one's face (i.e., eyes, nose, and mouth) & $\begin{array}{l}\text { Always } \\
\text { Occasionally } \\
\text { Never }\end{array}$ & $\begin{array}{l}\text { II (4.7\%) } \\
\text { I } 62(68.6 \%) \\
63(26.7 \%)\end{array}$ & $\begin{array}{l}10(4.2 \%) \\
158(66.9 \%) \\
68(28.8 \%)\end{array}$ \\
\hline Eating raw/fresh foods (raw meat, vegetables, etc.) before cooking or washing & $\begin{array}{l}\text { Always } \\
\text { Occasionally } \\
\text { Never }\end{array}$ & $\begin{array}{l}12(5.1 \%) \\
115(48.7 \%) \\
109(46.2 \%)\end{array}$ & $\begin{array}{l}14(5.9 \%) \\
102(43.2 \%) \\
120(50.8 \%)\end{array}$ \\
\hline $\begin{array}{l}\text { Participating in mass events (attending religious/cultural rituals, business/work meetings, social } \\
\text { gatherings, etc.) }\end{array}$ & $\begin{array}{l}\text { Always } \\
\text { Occasionally } \\
\text { Never }\end{array}$ & $\begin{array}{l}58(24.6 \%) \\
168(7 \mid .2 \%) \\
10(4.2 \%)\end{array}$ & $\begin{array}{l}62(26.3 \%) \\
168(71.2 \%) \\
6(2.5 \%)\end{array}$ \\
\hline
\end{tabular}

$88.6 \%$ of healthcare workers reported to wash their hands after touching objects, $30.1 \%$ revealed that their experience of regularly washing hands has decreased after taking the first round of COVID-19 vaccine. Moreover, 91.5\% of respondents clean their hands with disinfectants where there is no access to water and soap. In this regard, the findings of the present research are different from the findings of Hailu et al. ${ }^{7}$ who found low compliance to occupational health safety measures among healthcare workers in North Showa of Ethiopia. In addition, Gralton et al. ${ }^{23}$ found that intention to use a facemask was poor for care in single rooms but improved when patient contact is expected and when entering into multi-bed rooms in which perceived protectiveness of pre-exposure prophylaxis, vaccination, and a minimum 1 meter risk zone predicted facemask use among healthcare workers. On the other hand, Derksen et al. ${ }^{16}$ found frequent shortage of water, the presence of a culture promoting tolerance of dirtiness by the community, and healthcare organizational culture to be the factors affecting the safety of healthcare workers.

The results have also shown that the main reason of respondents for not regularly wearing a mask is its 
Table 4 Reasons for Not Complying with the Protective Behavioral Recommendations After Receiving the First- Round of COVID-I9 Vaccine

\begin{tabular}{|c|c|c|c|}
\hline & \multicolumn{2}{|c|}{ Responses } & \multirow[t]{2}{*}{ Percent of Cases } \\
\hline & $\mathbf{N}$ & Percent & \\
\hline \multicolumn{4}{|l|}{ I. Reasons for not regularly wearing a mask after taking the first round of COVID-19 vaccine } \\
\hline I believe that the first round of COVID-19 vaccine is sufficient to prevent infection & 8 & $7.1 \%$ & $12.3 \%$ \\
\hline Due to its inconvenience/discomfort & 39 & $34.8 \%$ & $60.0 \%$ \\
\hline I just want to appear indifferent because most people around me do not wear a mask & 25 & $22.3 \%$ & $38.5 \%$ \\
\hline I cannot afford to buy one because of its cost & 10 & $8.9 \%$ & $15.4 \%$ \\
\hline I do not believe that a mask can prevent infection & 9 & $8.0 \%$ & $13.8 \%$ \\
\hline I do not believe that COVID-I9 really exists & 2 & $1.8 \%$ & $3.1 \%$ \\
\hline I believe that I have adequate natural immunity & I & $0.9 \%$ & $1.5 \%$ \\
\hline I believe that I am not at risk of being infected by COVID-I9 & 5 & $4.5 \%$ & $7.7 \%$ \\
\hline I believe that I can easily withstand the illness if infected by the disease & 2 & $1.8 \%$ & $3.1 \%$ \\
\hline Lack of adequate information about it & 3 & $2.7 \%$ & $4.6 \%$ \\
\hline COVID-I9 is not that serious a concern in my work or residential area & I & $0.9 \%$ & $1.5 \%$ \\
\hline Other reasons & I & $0.9 \%$ & $1.5 \%$ \\
\hline No reason & 6 & $5.4 \%$ & $9.2 \%$ \\
\hline Total & 112 & $100.0 \%$ & $172.3 \%$ \\
\hline \multicolumn{4}{|l|}{ 2. Reasons for not frequently washing hands after taking the first round of COVID-19 vaccine } \\
\hline I believe that the first round of COVID-19 vaccine is sufficient to prevent infection & 6 & $10.2 \%$ & $16.2 \%$ \\
\hline Lack of access to water/soap & 15 & $25.4 \%$ & $40.5 \%$ \\
\hline I avoid touching of objects from the outset & 5 & $8.5 \%$ & $13.5 \%$ \\
\hline I do not believe that COVID-19 really exists & I & $1.7 \%$ & $2.7 \%$ \\
\hline I do not believe that washing hands can prevent infection & 2 & $3.4 \%$ & $5.4 \%$ \\
\hline Because I use chemical disinfectants instead of washing my hands & 10 & $16.9 \%$ & $27.0 \%$ \\
\hline I believe that I am not at risk of being infected by COVID-19 & 2 & $3.4 \%$ & $5.4 \%$ \\
\hline I believe that I can easily withstand the illness if infected by the disease & 3 & $5.1 \%$ & $8.1 \%$ \\
\hline Reasons related to belief/religion & 2 & $3.4 \%$ & $5.4 \%$ \\
\hline COVID-19 is not that serious a concern in my work or residential area & 2 & $3.4 \%$ & $5.4 \%$ \\
\hline Other reasons & 3 & $5.1 \%$ & $8.1 \%$ \\
\hline No reason & 8 & $13.6 \%$ & $21.6 \%$ \\
\hline Total & 59 & $100.0 \%$ & $159.5 \%$ \\
\hline \multicolumn{4}{|c|}{ 3. Reasons for not cleaning hands with disinfectants after taking the first round of COVID-19 vaccine } \\
\hline I believe that the first round of COVID-19 vaccine is sufficient to prevent infection & 6 & $18.2 \%$ & $20.7 \%$ \\
\hline Lack of access to hand sanitizer/alcohol & 8 & $24.2 \%$ & $27.6 \%$ \\
\hline
\end{tabular}

(Continued) 
Table 4 (Continued).

\begin{tabular}{|l|r|r|r|}
\hline & \multicolumn{2}{|c|}{ Responses } & \multirow{2}{*}{ Percent of Cases } \\
\cline { 2 - 4 } & $\mathbf{N}$ & Percent & \\
\hline I avoid touching of objects from the outset & 7 & $21.2 \%$ & $24.1 \%$ \\
\hline I believe that I have adequate natural immunity & 3 & $9.1 \%$ & $10.3 \%$ \\
\hline Lack of adequate information & I & $3.0 \%$ & $3.4 \%$ \\
\hline Reasons related to belief/religion & 2 & $6.1 \%$ & $6.9 \%$ \\
\hline COVID-I9 is not that serious a concern in my work or residential area & 1 & $3.0 \%$ & $3.4 \%$ \\
\hline No reason & 5 & $15.2 \%$ & $17.2 \%$ \\
\hline Total & 33 & $100.0 \%$ & $113.8 \%$ \\
\hline
\end{tabular}

inconvenience $(60 \%)$, followed by the need to appear indifferent because most people around the respondents do not wear mask (38.5\%), and cannot afford buying one due to its cost (15.4\%). Moreover, lack of access to water/soap has been found to be the major reason $(40.5 \%)$ for the healthcare workers not to frequently wash hands after touching objects, followed by the use of chemical disinfectants as a preferred alternative (27\%), and the belief that the first round of COVID-19 vaccine is sufficient to prevent infection (16.2\%). Derksen et al. ${ }^{16}$ found longstanding water scarcity, tolerance of dirtiness by the community, and healthcare organizational culture to be the major barriers to compliance with protective behavioral recommendations among obstetric healthcare workers. Diwan et al. ${ }^{17}$ added high workload, scarcity of resources, lack of scientific information, and the perception that priority is not given to hand hygiene either at an individual or institutional level serving as barriers to maintaining good hand hygiene among healthcare workers in rural India. Boti et al. ${ }^{18}$ identified various institutional, cultural, social, and personal barriers, including negligence, inadequate training for healthcare workers, and poor supportive supervision hindering the effective implementation of public health measures for containing the fast spread of COVID-19 in Southern Ethiopia. Moore et al. ${ }^{15}$ noted that organizational circumstances, such as a positive safety climate is associated with increased healthcare workers' adherence to universal precautions against SARS and other respiratory pathogens and suggested that providing rigorous training to healthcare workers can serve as an effective tool in changing their behavior.

The results of binary logistic regression analysis reveal that respondents' compliance with regular wearing of a mask is significantly associated with the sex of respondents $(\mathrm{OR}=3.165, \mathrm{P}<0.05$; 95\%CI: 1.186-8.448), the type of organization in which they are currently working $(\mathrm{OR}=3.553, \mathrm{P}<0.05 ; 95 \% \mathrm{CI}: 1.185-10.647)$, knowing someone ever infected by COVID-19 (OR=0.091, $\mathrm{P}<0.001$; 95\%CI: $0.030-0.275)$, and the belief that COVID-19 causes a severe illness $(\mathrm{OR}=0.249, \mathrm{P}<0.05$; 95\%CI: 0.299-2.615). Derksen et al. ${ }^{16}$ found an increasing compliance and adaptation to hand hygiene behavior among obstetric healthcare workers in Germany to prevent COVID-19 pandemic where the intention to sanitize hands is significantly associated with health workers' level of self-efficacy. On the other hand, Marjadi et al. ${ }^{20}$ uncovered that compliance to hand hygiene practices among rural Indonesian healthcare workers is poor and when it is done, it is more likely to be undertaken after direct contact with patients. Furthermore, Diwan et al. ${ }^{17}$ found high but varying among groups self-reported practices of hand hygiene among healthcare workers in rural India where previous training on the topic determines the level of selfreported practice of hand hygiene. DeJoy et al. ${ }^{19}$ argues that the effort of minimizing the risks of exposure to pathogens among healthcare workers requires a systemlevel perspective. Marjadi et al. ${ }^{20}$ stressed the need for interventions that focus on long-term community education to successfully protect healthcare workers from infection and fatalities. 
Table 5 Coefficients of Binary Logistic Regression Showing Association Between Regular Mask Wearing Practices and SocioDemographic Characteristics

\begin{tabular}{|c|c|c|c|c|c|c|c|}
\hline \multirow[t]{2}{*}{ Variables } & \multirow[t]{2}{*}{ Categories } & \multicolumn{3}{|c|}{$\begin{array}{l}\text { Do You Regularly Wear } \\
\text { a Mask? }\end{array}$} & \multirow[t]{2}{*}{$P$ value } & \multirow[t]{2}{*}{ OR } & \multirow[t]{2}{*}{$95 \% \mathrm{Cl}$} \\
\hline & & Yes & No & Total & & & \\
\hline \multirow[t]{3}{*}{ Sex } & Male & 79 & 35 & 114 & $0.021^{*}$ & 3.165 & I. $186-8.448$ \\
\hline & Female & 107 & 15 & 122 & & & \\
\hline & Total & 186 & 50 & 236 & & & \\
\hline \multirow[t]{3}{*}{ Have children } & Yes & 118 & 31 & 149 & 0.731 & 1.309 & $0.28 I-6.094$ \\
\hline & No & 68 & 19 & 87 & & & \\
\hline & Total & 186 & 50 & 236 & & & \\
\hline \multirow[t]{9}{*}{ Occupation } & Medical doctor & 18 & 2 & 20 & 0.859 & 0.757 & $0.035-16.161$ \\
\hline & Health officer & 28 & 14 & 42 & & & \\
\hline & Administrative staff & 23 & 4 & 27 & & & \\
\hline & Nurse & 82 & 13 & 95 & & & \\
\hline & Pharmacist & 22 & 6 & 28 & & & \\
\hline & Security & 0 & 7 & 7 & & & \\
\hline & Janitor & 3 & 2 & 5 & & & \\
\hline & Medical laboratory & 10 & 2 & 12 & & & \\
\hline & Total & 186 & 50 & 236 & & & \\
\hline \multirow[t]{3}{*}{ Organization } & Public & 86 & 26 & 112 & $0.024^{*}$ & 3.553 & $1.185-10.647$ \\
\hline & Private & 23 & 11 & 34 & & & \\
\hline & Charity & 77 & 13 & 236 & & & \\
\hline \multirow[t]{3}{*}{ Know someone infected by COVID-I9 } & Yes & 150 & 26 & 176 & $0.000 * * *$ & 0.091 & $0.030-0.275$ \\
\hline & No & 36 & 24 & 60 & & & \\
\hline & Total & 186 & 50 & 236 & & & \\
\hline \multirow[t]{3}{*}{ Know someone who died of COVID-19 } & Yes & 91 & 20 & 111 & 0.081 & 2.800 & $0.879-8.917$ \\
\hline & No & 95 & 30 & 125 & & & \\
\hline & Total & 186 & 60 & 236 & & & \\
\hline \multirow[t]{3}{*}{ Perceived susceptibility to COVID-19 } & Yes & 103 & 20 & 123 & 0.977 & 1.016 & $0.345-2.996$ \\
\hline & No & 83 & 30 & 113 & & & \\
\hline & Total & 186 & 50 & 236 & & & \\
\hline \multirow[t]{3}{*}{ Perceive COVID-19 causes severe illness } & Yes & 153 & 30 & 183 & $0.04 I^{*}$ & 0.249 & $0.066-0.944$ \\
\hline & No & 33 & 20 & 53 & & & \\
\hline & Total & 186 & 50 & 236 & & & \\
\hline \multirow[t]{3}{*}{ Belief about the likelihood of dying from COVID- 19} & Yes & 72 & 20 & 92 & 0.824 & 0.884 & $0.299-2.615$ \\
\hline & No & 114 & 30 & 144 & & & \\
\hline & Total & 186 & 50 & 236 & & & \\
\hline
\end{tabular}

Notes: $* * * \mathrm{P}<0.001 ; * \mathrm{P}<0.05$

Abbreviations: OR, Odds Ratio; $\mathrm{Cl}$, Confidence Interval.

\section{Conclusion}

The aim of the study was to assess the changes in compliance with the protective behavioral recommendations after taking the first round of COVID-19 vaccine among healthcare workers in Southern Ethiopia. Although the level of compliance has remained unchanged among most healthcare workers, we have also found significant reductions in adherence to the usual protective mechanisms which have emanated from excessive reliance on the immunizing power of the first round of COVID-19 vaccine, the lack of access to water and soap in and around the healthcare facilities, the presence of inconvenience 
related to wearing a mask, the need for appearing indifferent among the non-complying crowd, and the lack of access to hand sanitizers among the healthcare workers. Moreover, the study has also found that being a female healthcare worker, serving in public healthcare organizations, being exposed to someone ever infected by COVID19, and believing that one would die if infected by COVID-19 significantly determine healthcare workers' tendency of regularly wearing a mask. Therefore, authorities in charge of managing the healthcare facilities should work to make most, if not all, the necessary personal protective equipment accessible to the healthcare workers. In addition to the reports of the healthcare workers, our field observation during data collection has made it clear that access to water in most Ethiopian healthcare organizations is difficult and that this creates barriers to maintaining sanitation. It is therefore important that continuous water supply be made for the healthcare facilities.

\section{Data Sharing Statement}

The data used to support the findings of this study are available from the corresponding author upon reasonable request.

\section{Ethics Approval and Consent to Participate}

The study was approved by the Ethics Approval Committee of Wolaita Sodo University. Written informed consent forms were signed by all research participants. In addition, a formal letter was obtained from the Department of Sociology, Wolaita Sodo University. Moreover, research participants were informed ahead about the possibility of withdrawing from the study in case the need arises at any time. Above all, this study was conducted in accordance with the Declaration of Helsinki.

\section{Acknowledgment}

All individuals and groups who have taken part in the successful accomplishment of the research, especially, the head of the College of Social Sciences and Humanities of Wolaita Sodo University (Mr. Abreham Kebede), medical directors and other administrative heads of the healthcare facilities, especially Mr. Tamiru Mengistu, where we have collected data, and healthcare workers who have shown keen interest of participating in our survey deserve appreciation.

\section{Disclosure}

The authors declare that there are no conflicts of interest.

\section{References}

1. Pfefferbaum B, North CS. Mental health and the Covid-19 pandemic. N Engl J Med. 2020;386(6):510-512. doi:10.1056/NEJMp2008017

2. World Health Organization. Rational use of personal protective equipment for coronavirus disease 2019 (COVID-19): interim guidance. World Health Organization; 2020.

3. Bielicki J, Duval X, Gobat N, et al. Monitoring approaches for health-care workers during the COVID-19 pandemic. Lancet Infect Dis. 2020;20:e261-e267. doi:10.1016/S1473-3099(20)30458-8

4. Liu Q, Luo D, Haase JE, et al. The experiences of health-care providers during the COVID-19 crisis in China: a qualitative study. Lancet Glob Health. 2020;8:e790-e798. doi:10.1016/S2214-109X (20)30204-7

5. World Health Organization. Coronavirus disease (COVID-19) outbreak: rights, roles and responsibilities of health workers, including key considerations for occupational safety and health. World Health Organization; 2020. Available from: https://www.who.int/docs/ default-source/coronaviruse/who-rights-roles-respon-hw-COVID-19. pdf?sfvrsn=bcabd4010. Accessed August 13, 2021.

6. Woyessa AH, Oluma A, Palanichamy T, et al. Predictors of healthcare workers' unwillingness to continue working during the peak of COVID-19 in Western Ethiopia: an extended parallel-process model study. Risk Manag Healthc Policy. 2021;14:1165-1173. doi:10.2147/ RMHP.S288003

7. Hailu D, Benayew M, Liknaw T, et al. Occupational health safety of health professionals and associated factors during COVID-19 pandemics at North Showa Zone, Oromia Regional State, Ethiopia. Risk Manag Healthc Policy. 2021;14:1299-1310. doi:10.2147/RMHP. S292830

8. Lauer SA, Grantz KH, Bi Q, et al. The incubation period of coronavirus disease 2019 (COVID-19) from publicly reported confirmed cases: estimation and application. Ann Intern Med. 2020;172 (9):577-582. doi:10.7326/M20-0504

9. Dorman P. The economics of safety, health, and well-being at work: an overview. Geneva: International Labor Organization the Evergreen State College; 2020.

10. Health and Safety Authority. Workplace safety and health management: practical guidelines on the implementation and maintenance of an occupational safety, health and welfare management system. Health and Safety Authority; 2006.

11. Bhaskar S, Rastogi A, Menon KV, Kunheri B, Balakrishnan S, Howick J. Call for action to address equity and justice divide during COVID-19. Front Psychiatry. 2020;11:559905. doi:10.3389/ fpsyt.2020.559905

12. Sharma D, Bhaskar S. Addressing the Covid-19 burden on medical education and training: the role of telemedicine and tele-education during and beyond the pandemic. Front Public Health. 2020;8:589669. doi:10.3389/fpubh.2020.589669

13. Bhaskar S, Tan J, Bogers MLAM, et al. At the epicenter of COVID-19-the tragic failure of the global supply chain for medical supplies. Front Public Health. 2020;8:562882. doi:10.3389/ fpubh. 2020.562882

14. Yassi A, Bryce E, Moore D, et al. Protecting the faces of health care workers: knowledge gaps and research priorities for effective protection against occupationally acquired respiratory infectious diseases. 2004.

15. Moore D, Gamage B, Bryce E, Copes R, Yassi A. Protecting health care workers from SARS and other respiratory pathogens: organizational and individual factors that affect adherence to infection control guidelines. Am J Infect Control. 2005;33(2):88-96. doi:10.1016/j. ajic.2004.11.003 
16. Derksen C, Keller FM, Lippke S. Obstetric healthcare workers' adherence to hand hygiene recommendations during the COVID-19 pandemic: observations and social-cognitive determinants. Appl Psychol Health Well Being. 2020;12(4):1286-1305.

17. Diwan V, Gustafsson C, Rosales Klintz S, et al. Understanding healthcare workers self-reported practices, knowledge and attitude about hand hygiene in a medical setting in rural India. PLoS One. 2016;11(10):e0163347. doi:10.1371/journal.pone.0163347

18. Boti SN, Hussen S, Shibiru T, et al. Exploring barriers to effective implementation of public health measures for prevention and control of COVID-19 pandemic in Gamo Zone of Southern Ethiopia: using a modified Tanahashi model. Risk Manag Healthc Policy. 2021;14:1219-1232. doi:10.2147/RMHP.S297114

19. DeJoy DM, Gershon RRM, Murphy LR, Wilson MG. A work-systems analysis of compliance with universal precautions among health care workers. Health Educ Q. 1996;23(2):159-174. doi:10.1177/109019819602300203

20. Marjadi BM, McLaws ML. Hand hygiene in rural Indonesian healthcare workers: barriers beyond sinks, hand rubs and in-service training. $J$ Hosp Infect. 2010;76(3):256-260. doi:10.1016/j. jhin.2010.06.021

21. Majeed A, Hussain I, Imran I, et al. Assessing barriers faced by surgeons while providing surgical care during the COVID-19 pandemic in Pakistan: an online cross-sectional study. $J$ Multidiscip Healthc. 2021;14:665-672. doi:10.2147/JMDH.S300008

22. Alwazzan RA, Baseer MA, ALMugeiren OM, Ingle NA. Dental professional's knowledge, preventive awareness and attitude towards COVID-19 in Saudi Arabia: a cross-sectional survey. Risk Manag Healthc Policy. 2021;14:2277-2288. doi:10.2147/RMHP.S303858
23. Gralton J, Rawlinson WR, DipTrop ML. Health care workers' perceptions predicts uptake of personal protective equipment. $\mathrm{Am}$ J Infect Control. 2013;14(1):2-7. doi:10.1016/j.ajic.2012.01.019

24. Zewude B, Habtegiorgis T. Willingness to take COVID-19 vaccine among people most at risk of exposure in Southern Ethiopia. Pragmat Obs Res. 2021;12:37-47. doi:10.2147/POR.S313991

25. Kumar R, Srivastava JK, Singh R, et al. Available compounds with therapeutic potential against COVID-19: antimicrobial therapies, supportive care, and probable vaccines. Front Pharmacol. 2020;11:582025. doi:10.3389/fphar.2020.582025

26. Esakandari H, Nabi-Afjadi M, Fakkari-Afjadi J, Farahmandian N, Miresmaeil MS, Bahreini E. A comprehensive review of COVID-19 characteristics. Biol Proced Online. 2020;22:1-10. doi:10.1186/ s12575-020-00128-2

27. Bedford J, Enria D, Giesecke J, et al. WHO strategic and technical advisory group for infectious hazards. COVID-19: towards controlling of a pandemic. Lancet. 2020;395:1015-1018. doi:10.1016/ S0140-6736(20)30673-5

28. Kassa AM, Mekonnen AM, Yesuf KA, Tadesse AW, Bogale GG. Knowledge level and factors influencing prevention of COVID-19 pandemic among residents of Dessie and Kombolcha City administrations, North-East Ethiopia: a population-based cross-sectional study. BMJ Open. 2020;10:e044202. doi:10.1136/bmjopen-2020044202
Risk Management and Healthcare Policy

\section{Publish your work in this journal}

Risk Management and Healthcare Policy is an international, peerreviewed, open access journal focusing on all aspects of public health, policy, and preventative measures to promote good health and improve morbidity and mortality in the population. The journa welcomes submitted papers covering original research, basic science, clinical \& epidemiological studies, reviews and evaluations,
Dovepress

guidelines, expert opinion and commentary, case reports and extended reports. The manuscript management system is completely online and includes a very quick and fair peer-review system, which is all easy to use. Visit http://www.dovepress.com/testimonials.php to read real quotes from published authors. 